\title{
Enviromental Pattern Analysis of Biodiesel (Castor, Coconut, MGB) to Support Alternative Energy using CFD approach
}

\author{
Sutrisno *, Avando Bastari and Okol Sri Suharyo \\ Indonesian Naval Technology College, STTAL Surabaya Indonesia.
}

Global Journal of Engineering and Technology Advances, 2021, 08(01), 051-060

Publication history: Received on 01 June 2021; revised on 07 July 2021; accepted on 09 July 2021

Article DOI: https://doi.org/10.30574/gjeta.2021.8.1.0100

\begin{abstract}
The Ship uses the MTU 16V956 TB 92 propulsion engine with a piston-type Mexican Hat combustion chamber. In general, the crown is used on machines with large torque. Besides that, the crown shape in the combustion chamber is also very influential on the formation of a mixture of fuel and air before the combustion process occurs. So it is necessary to know about the spray pattern of biodiesel fuel of enviromental things (castor, coconut, used cooking oil/MGB) in the Mexican Hat combustion chamber. In this study, using the Mexican Hat-shaped piston crown simulation method, the first step was to test the spray pattern of the three types of biodiesel (castor, coconut, used cooking oil) by simulating a tube with an injection pressure of 350 bar gauge pressure inside a barometric pressure tube. While the completion in the Mexican Hat combustion chamber with a chamber pressure of 35 bar gauge and injection pressure of 350 bar gauge was completed with the CFD program, Fluent 6.2, and the results of the three biodiesels were compared. From the CFD simulation results obtained spray patterns of the three types of biodiesel (castor, coconut, used cooking oil). At the same injection pressure and chamber pressure, used cooking biodiesel has the longest penetration length, followed by castor biodiesel and coconut biodiesel. The spray angle of coconut biodiesel is the largest, followed by castor biodiesel and used cooking oil biodiesel. SMD coconut biodiesel is the smallest, followed by castor biodiesel and used cooking oil biodiesel.
\end{abstract}

Keywords: Enviromental; Biodiesel; Castor, Coconut, Cooking oil/MGB; Pattern Analysis

\section{Introduction}

In the Indonesian National Armed Forces environment, the Navy, especially the Republic of Indonesia Navy Ships A, uses a propulsion engine with the MTU type 16V956 TB 92. Where the engine uses a piston-type Mexican Hat combustion chamber because in general the crown type is used in engines - with large torque.

On the other hand, in dealing with air pollution, exhaust emissions from motor vehicles in the form of solid particulate matter (PM), CO, HC, and NOx must be kept as low as possible below the allowable number. The four types of emissions have direct (short-term) effects on humans. While the long-term effects caused by emissions are those that affect the atmosphere. A recent report from the IPCC (Intergovernmental Panel on Climate Change) concluded that CO. concentrations ${ }_{2}, \mathrm{CH}_{4}$, and NOx in the global atmosphere have increased due to human activities since 1750 . The global increase in CO. levels ${ }_{2}$ in the atmosphere, the main cause is the emission of exhaust gases from combustion in the combustion engine.

Fossil fuels will eventually run out because fossil fuels cannot be renewed. This has made various groups in the country aware that dependence on fossil fuels needs to be gradually reduced, coupled with the bad effect of burning fossil fuels

\footnotetext{
${ }^{*}$ Corresponding author: Sutrisno

Indonesian Naval Technology College, STTAL Surabaya Indonesia.

Copyright $(2021$ Author(s) retain the copyright of this article. This article is published under the terms of the Creative Commons Attribution Liscense 4.0.
} 
on the environment, it is also a driving factor in the search and development of alternative energy sources, non-fossil fuels.

\section{Literature review}

\subsection{Biodiesel Enviroment Material}

In this stage, we determine the type of material to be used and enter the data properties of the material. The material injected is biodiesel (castor, coconut, MGB) with the following properties.

Table 1 Material Characteristic

\begin{tabular}{|l|c|c|c|}
\hline Material & $\begin{array}{c}\text { Density } \\
\text { (kg/m3) }\end{array}$ & $\begin{array}{c}\text { Dynamic Viscosity } \\
\text { (kg/ms) }\end{array}$ & $\begin{array}{c}\text { Surface tension } \\
\mathbf{( N / m ) ~}\end{array}$ \\
\hline Castor & 906.6 & 0.01618 & 0.0699 \\
\hline Coconut & 880.4 & 0.00685 & 0.0621 \\
\hline MGB & 915.7 & 0.034347 & 0.073 \\
\hline
\end{tabular}

\subsection{Workpiece Model Schematic}

Workpiece or simulated geometry model as follows:

\subsubsection{Cylinder Tube}
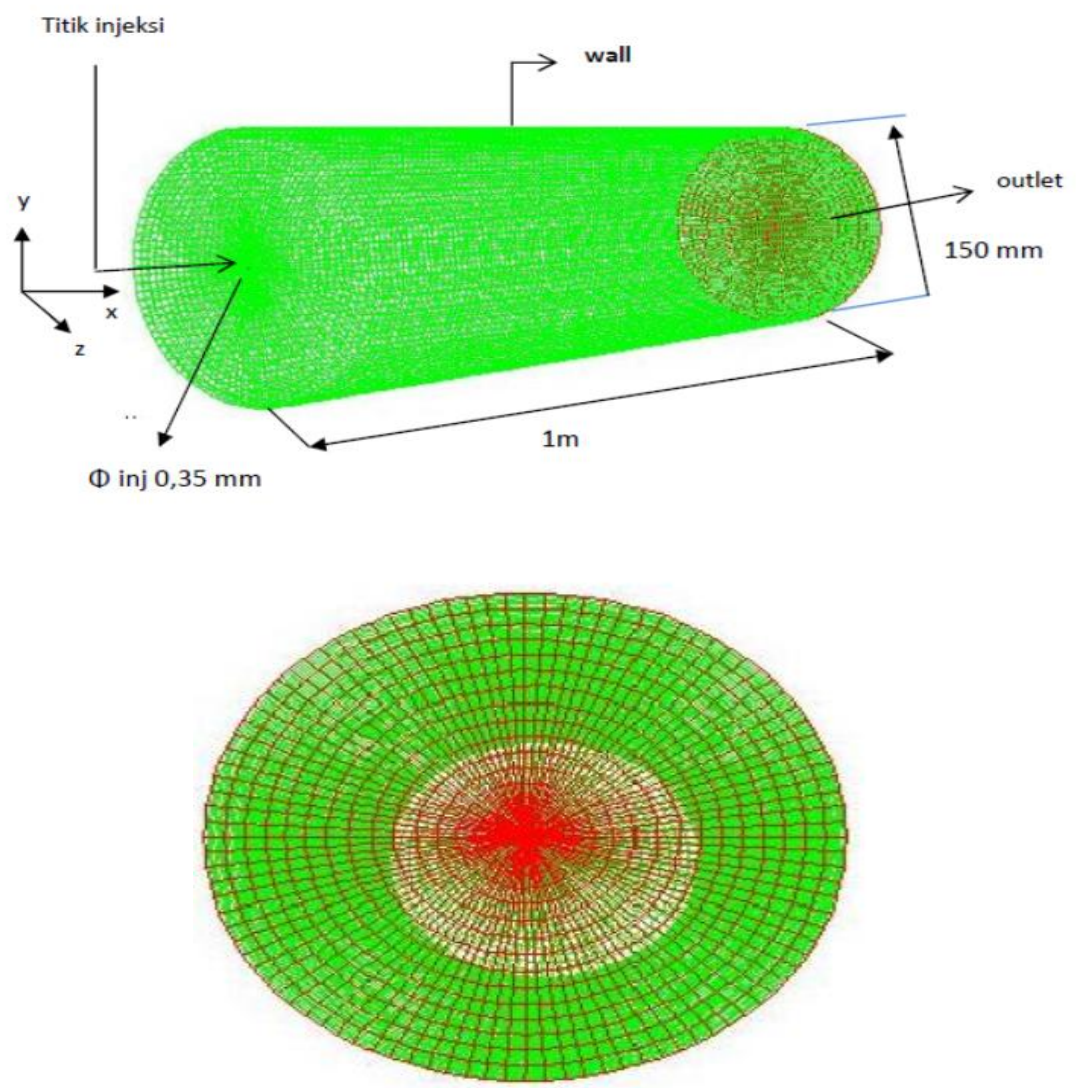

Figure 1 Model Geometry, Mesh, and Boundary Enviromental Things Conditions 

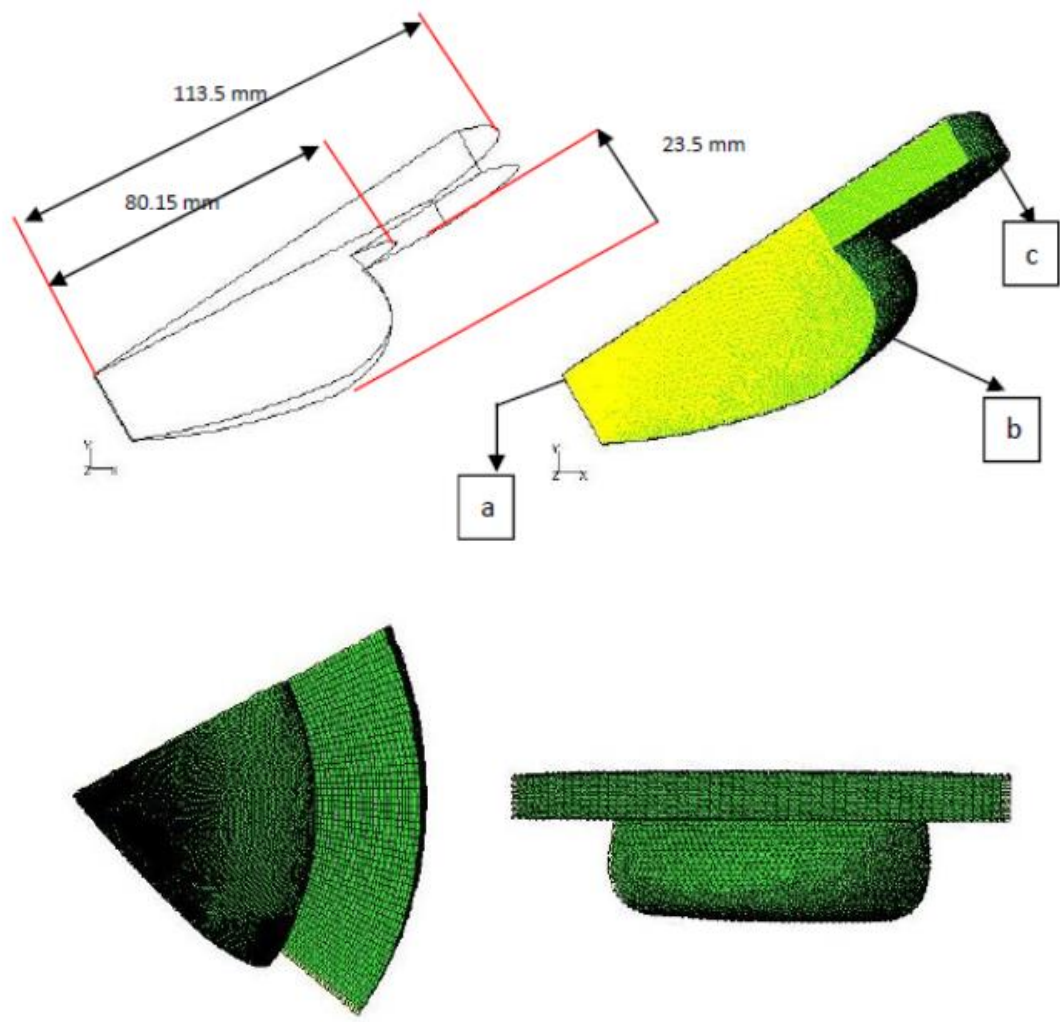

Figure 2 Mexican Hat geometric model drawing, mesh, and boundary conditions

Where:

a. Injector hole

b. Crown Mexican Hat

c. Injector castor

\section{Results and discussion}

The initial stage in analyzing the effect of modifying/redesigning the bow of the 60-meter missile fast boat (KCR-60) using the axe bow type against obstacles and speed is the ship modeling process using 3D design software, namely Maxsurf Modeller Advanced V8i software that then for the testing phase and data processing using several analysis programs from the Maxsurf Resistance V8i software and using the MARIN DESPPC 1999 program which all plays a role in processing the data on the calculation of resistance that occurs on the ship by testing several variations of the specified speed. Tests with ship speed will be carried out in several variations of speed to determine changes in the value of resistance that occur based on changes in ship speed which are increasingly being increased; The speed variations that will be used are 15 knots, 20 knots, 25 knots, 28 knots, and 30 knots.

\subsection{Fuel Mass Flow Rate}

From the $\mathrm{Cd}$ obtained in the previous study, namely $\mathrm{Cd}=0.832$, it can be calculated the mass flow rate of the fuel which is a function of the pressure difference $(\Delta \mathrm{p})$ like equation $\dot{m}=C_{d} \cdot A_{n} \cdot \sqrt{2 \cdot \rho_{f} \cdot \Delta P}$

Where:

CD = nozzle discharge coefficient

$\mathrm{f} \quad$ = fuel density

$\mathrm{V} \quad=$ fuel volume per spray 
= spray duration

An $\quad=$ nozzle hole cross-sectional area

$\mathrm{p}=$ = difference between injection pressure and chamber pressure

$\dot{m} \quad=$ mass flow rate

Example of calculating mass flow rate for coconut biodiesel

Is known:

$$
\begin{array}{ll}
\mathrm{CD} & =0.832 \\
\mathrm{Dn} & =0.00035 \mathrm{~m} \\
\mathrm{Pi} & =350 \times 10^{5} \mathrm{~N} / \mathrm{m} \\
\mathrm{P} & =349 \times 10^{5} \mathrm{~N} / \mathrm{m} \\
\mathrm{PC} & =1 \times 10^{5} \mathrm{~N} / \mathrm{m} \\
\mathrm{f} & =880.4 \mathrm{~kg} / \mathrm{m} 3 \\
\mathrm{An} & =\times 3.14 \times(0.00035 \mathrm{~m})^{2} \\
& \quad=9.61625 \times 10^{-8} \mathrm{~m} 2
\end{array}
$$

$\dot{m}=C_{d} \cdot A_{n} \cdot \sqrt{2 \cdot \rho_{f} \cdot \Delta P}$

$\dot{m}=0,832 \times 9,61625 \times 10^{-8} \mathrm{~m}^{2} \cdot \sqrt{2 \times 880,4 \frac{\mathrm{kg}}{\mathrm{m}^{3}} \times 349 \times 10^{5} \mathrm{pa} \times \frac{\mathrm{N} / \mathrm{m}^{2}}{\mathrm{~Pa}} \times \frac{\mathrm{kgm} / \mathrm{s}^{2}}{\mathrm{~N}}}$

$\dot{m}=19,833 \times 10^{3} \mathrm{~kg} / \mathrm{s}$

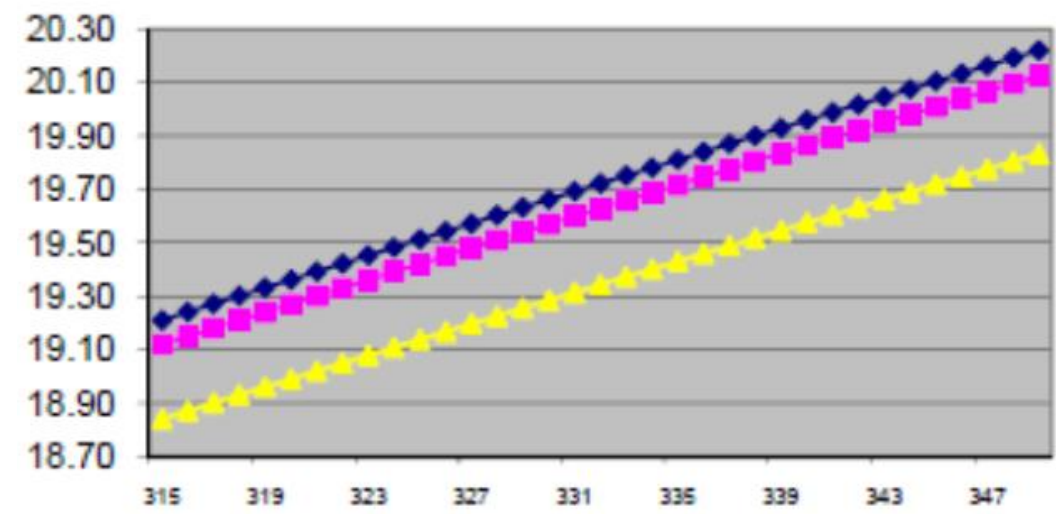

Figure 3 Mass Flow Rate of Fuel (Y) against the Pressure difference (X) at $\mathrm{Pi}=350$ Bar (Yellow: Coconut oil, Pink: Castor oil, Dark blue: MGB)

The calculation results show that the mass flow rate of castor biodiesel at different pressures $(\mathrm{Pi}=350 \mathrm{bar}$ and $\mathrm{Pc}=1$ bar) is $20.13 \mathrm{~g} / \mathrm{s}$. The mass flow rate of Coconut Biodiesel at the highest pressure difference $(\mathrm{Pi}=350 \mathrm{bar}$ and $\mathrm{Pc}=1$ 
bar) is $19.83 \mathrm{~g} / \mathrm{s}$. While the mass flow rate of used cooking oil biodiesel (MGB) at the highest pressure difference (Pi $=$ $350 \mathrm{bar}$ and $\mathrm{Pc}=1 \mathrm{bar}$ ) is $20.22 \mathrm{~g} / \mathrm{s}$.

\subsection{Visualization on Mexican Hat}

From the simulation results, a spray image can be obtained as shown in the following Figure:
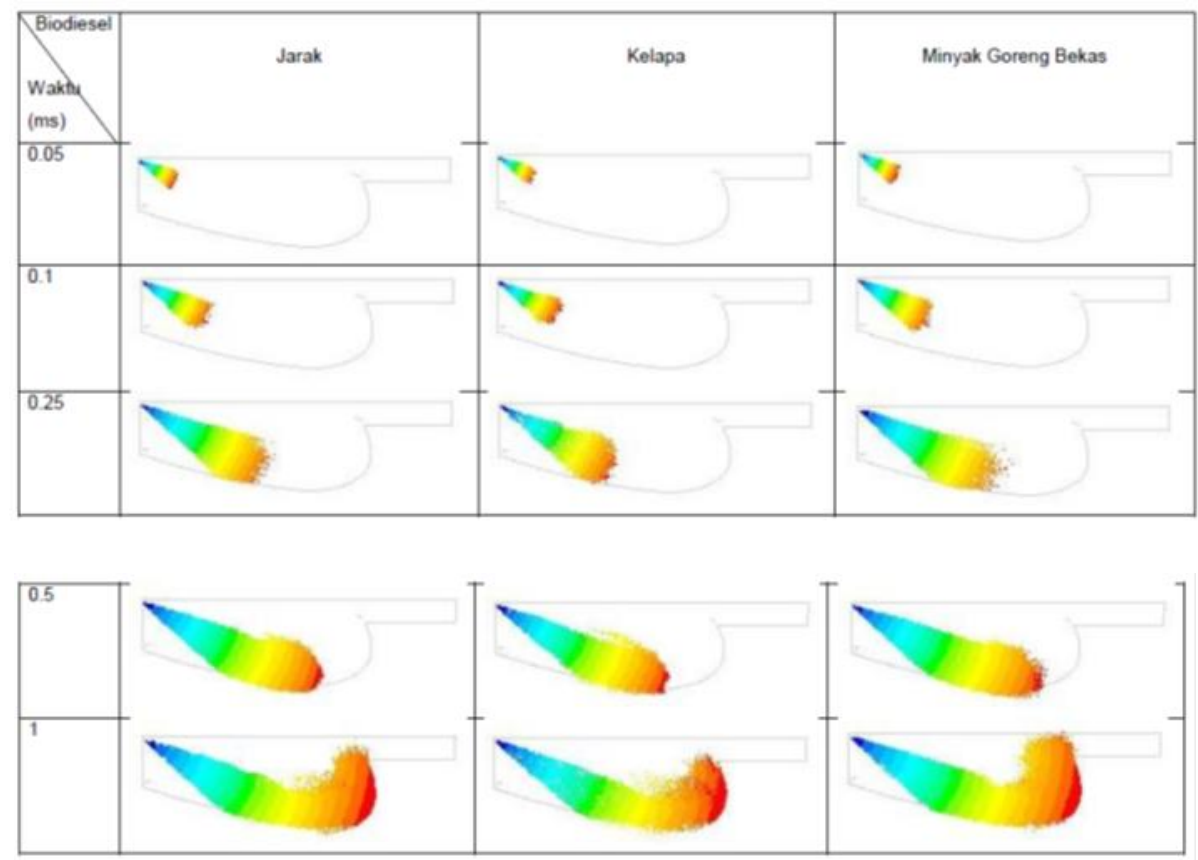

Figure 4 Enviromental Biodiesel Spray at a pressure of $\mathrm{Pi}=350$ bar $\mathrm{pc}=35$ bar in a Mexican Hat Combustion Chamber

\subsubsection{Penetration Length}

From the picture above, the visualization on Mexican Hat of the three biodiesels used, namely biodiesel (castor, coconut, used cooking oil) shows that the penetration length for the same injection pressure and chamber pressure gives different penetration lengths. This difference is due to the different properties of the biodiesel used. Used cooking oil biodiesel with the highest density of $915.2 \mathrm{~kg} / \mathrm{m}$, Castor biodiesel with a density of $906.6 \mathrm{~kg} / \mathrm{m}$, and coconut biodiesel with a density of $880.4 \mathrm{~kg} / \mathrm{m}^{3}$. Viscosity $(\mu)$ Castor biodiesel $0.0161828 \mathrm{~kg} / \mathrm{ms}$, coconut biodiesel $0.00684951 \mathrm{~kg} / \mathrm{ms}$, MGB $0.0343475 \mathrm{~kg} / \mathrm{ms}$ Surface tension $(\sigma)$ Castor biodiesel $0.0669(\mathrm{~N} / \mathrm{m})$, coconut biodiesel 0.0621 (N/m) and MGB $0.0730(\mathrm{~N} / \mathrm{m})$

Table 2 Penetration Length Visualization Results on Mexican Hat

\begin{tabular}{|c|c|c|c|}
\hline \multirow{2}{*}{$\begin{array}{l}\text { SOI } \\
\text { (ms) }\end{array}$} & \multicolumn{3}{|c|}{ Biodiesel Penetration Length (mm) } \\
\cline { 2 - 4 } & Castor & Coconut & MGB \\
\hline 0.05 & 14.6 & 14.1 & 15 \\
\hline 0.1 & 25.6 & 24 & 29.2 \\
\hline 0.25 & 49.9 & 46.8 & 57.5 \\
\hline 0.5 & 70.5 & 68.3 & 74.6 \\
\hline 1 & 84.3 & 84.3 & 84.3 \\
\hline
\end{tabular}

\subsubsection{Spray Angle}

The spray cone angle with the Equation (Heywood, JB, 1988) 


$$
\tan \frac{\theta}{2}=\frac{1}{A} 4 \pi\left(\frac{\rho_{\mathrm{g}}}{\rho_{\mathrm{l}}}\right)^{\frac{1}{2}} \frac{\sqrt{3}}{6}
$$

Where:

$\mathrm{g}=$ density of air $\left(\mathrm{kg} / \mathrm{m}^{3}\right)$

$\mathrm{l}=$ density of fuel $\left(\mathrm{kg} / \mathrm{m}^{3}\right)$

$\mathrm{A}=$ Constant of nozzle geometry, where in the above equation $\mathrm{A}=3.8$ (the empirical equation for the value of $\mathrm{A}$ is $\mathrm{A}=$ $3+0.28(\mathrm{Ln} / \mathrm{dn})$, where $\mathrm{Ln} / \mathrm{dn}$ is the ratio of nozzle length/diameter)

Example of calculating spray angle on coconut biodiesel

Is known:

$\mathrm{l}=880.4 \mathrm{~kg} / \mathrm{m}^{3}$

$\mathrm{a} \quad=40.4876 \mathrm{~kg} / \mathrm{m} 3$

A $\quad=3+0.28\left(\mathrm{Ln}_{\mathrm{n}} / \mathrm{dn}\right)$

$=3+0.28(1 \mathrm{~mm} / 0.35 \mathrm{~mm})$

$=3.8$

$$
\tan \frac{\theta}{2}=\frac{1}{3,8} 4 \pi\left(\frac{40,4876 \mathrm{~kg} / \mathrm{m}^{3}}{880,4 \mathrm{~kg} / \mathrm{m}^{3}}\right)^{\frac{1}{2}} \frac{\sqrt{3}}{6}
$$

$\theta \quad=23.14^{\circ}$

The spray angle of coconut biodiesel (B100) is greater than that of used cooking oil biodiesel and castor biodiesel. This is because the density of coconut biodiesel is smaller than that of used cooking oil and castor biodiesel. The low density of the fuel spray will make it easier for the air entrainment in the spray chamber so that more liquid spray is dispersed around the surroundings and the spray angle will be enlarged.

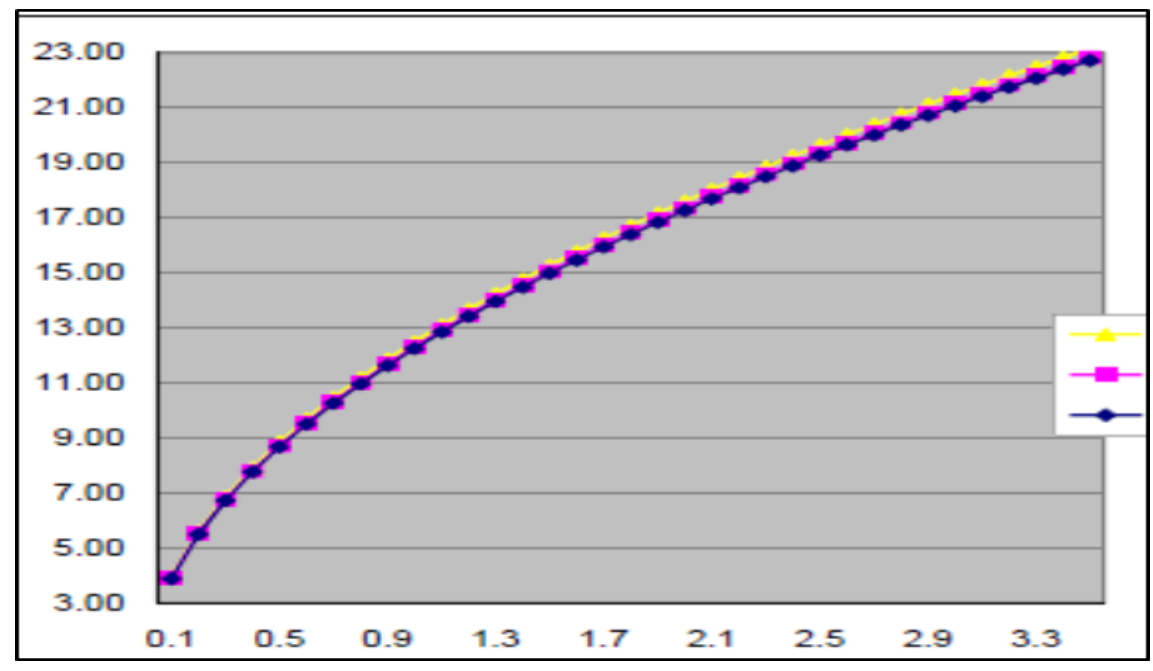

Figure 5 Cone Angle (Y) and Chamber Pressure (X) Graph Drawing

(Yellow: Coconut oil, Pink: Castor oil, Dark blue: MGB - Biodiesel Enviromental Things) 
In the graphic above, the largest spray angle is coconut biodiesel, then castor biodiesel, and finally used cooking oil biodiesel. Statistically, the three biodiesel angles are not significantly different, it can be seen in the graphic that the three types of biodiesel coincide. With $\mathrm{Pi}=350$ bar gauge and $\mathrm{Pc}=35$ bar gauge, the angle of biodiesel castor is $22.81^{\circ}$, coconut biodiesel is $23.14^{\circ}$, and used cooking oil biodiesel angle is $22.71^{\circ}$.

While the simulation results of the spray angle at $\mathrm{Pi}=350$ bar gauge and $\mathrm{Pc}=35$ bar gauge for a spray angle of $28^{\circ}$ castor biodiesel, $30^{\circ}$ coconut biodiesel, and $26^{\circ}$ used cooking oil biodiesel. The decrease in the physical properties of the fuel accelerates the occurrence of secondary break up so that the number of particles formed has a more diffuse dispersion pattern. As the dispersion pattern spreads, the coconut biodiesel has the highest spray angle.

\subsubsection{Average Droplet Sized}

The method that is often used to determine the average droplet size is to use the Sauter Mean Diameter (SMD). Based on the formulation given by Jasuja (Lefebvre and Arthur, 1991). That the greater the chamber pressure, the smaller the SMD for the three types of biodiesel.

Thus, to determine the grain size at the time of atomization, Jasuja's empirical formulation (Lefebvre and Arthur, 1991) with the injector type pressure swirl atomizer can be used:

$S M D=2,25 \sigma^{0,25} \mu_{L}^{0,25} \dot{m}_{L}^{0,25} \Delta P_{L}^{-0,5} \rho_{A}^{-0,25}$ Where:

high school = = Average Sauter diameter (Sauter Mean Diameter of Droplet), $\mathrm{m}$

$m \quad$ = Mass flow rate of liquid, $\mathrm{kg} / \mathrm{sec}$

$\sigma=$ Surface tension of the liquid, $\mathrm{N} / \mathrm{m}$

$\mathrm{PL}=$ Difference between the injector and air pressure, $\mathrm{Pa}$

A $\quad=$ Density of air, $\mathrm{kg} / \mathrm{m}^{3}$

$\mathrm{L} \quad=$ Viscosity of the liquid, $\mathrm{kg} / \mathrm{m} . \mathrm{sec}$

Example of SMD calculation for coconut biodiesel

$$
\begin{aligned}
S M D= & 2,25 \times\left(0,0621 \frac{\mathrm{N}}{\mathrm{m}}\right)^{0,25} \times\left(0,00685 \frac{\mathrm{kg}}{\mathrm{m} \cdot \mathrm{sec}}\right)^{0,25} \times\left(0,01983 \frac{\mathrm{kg}}{\mathrm{sec}}\right)^{0,25} \times\left(3,49 \times 10^{7} \frac{\mathrm{N}}{\mathrm{m}^{2}}\right)^{-0,5}=19,792 \times \\
& \times\left(1,15678 \frac{\mathrm{kg}}{\mathrm{m}^{3}}\right)^{-0,25}
\end{aligned}
$$

$10-6 \mathrm{~m}=19,792 \mathrm{~m}$

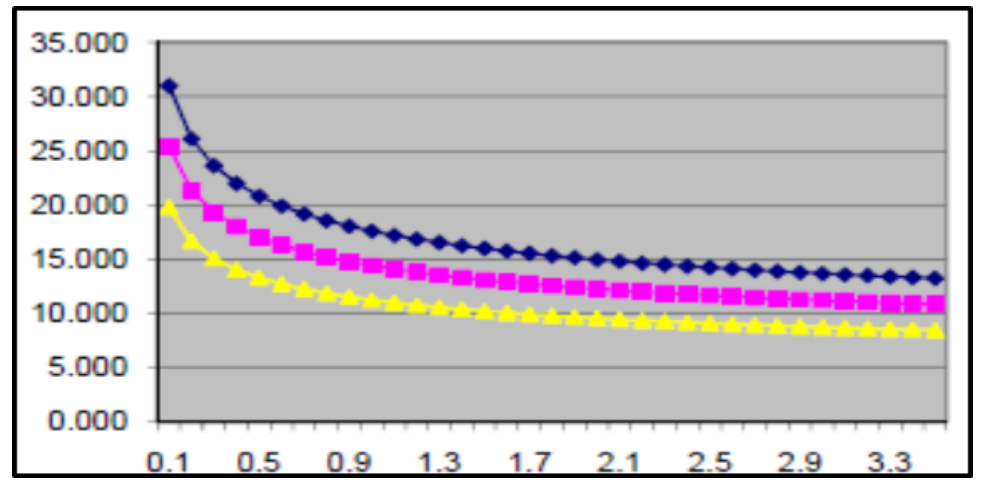

Figure 6 The graph between SMD (Y) and Chamber Pressure (X) at Pi = 350 Bar gauge (Yellow: Coconut oil, Pink: Castor oil, Dark blue: MGB - Biodiesel Enviromental Things) 
Based on the graphic image at a fixed injection pressure (Pi) of 350 bar gauge with increasing chamber pressure, the SMD of the three types of biodiesel looks smaller. With an increase in chamber pressure of 35 bar, the SMD for Castor, Coconut and Used Cooking Oil (MGB) biodiesel fuels decreased by $14.5 \mathrm{~m}$ and $11.3 \mathrm{~m}, 17.7 \mathrm{~m}$, respectively. This is because the higher the chamber pressure, the higher the air density in the chamber. So that the friction occurs in the larger droplets which results in faster break-up followed by the breakdown of the droplets into smaller droplets. In the picture condition $\mathrm{t}=1 \mathrm{~ms}$, the color image shows the droplet diameter size, it can be seen that the diameter size difference of the three types of biodiesel is visible. The green color is 0,0107 mm diameter castor biodiesel, $0.00552 \mathrm{~mm}$ diameter coconut biodiesel, and $0.0162 \mathrm{~mm}$ diameter MGB biodiesel.

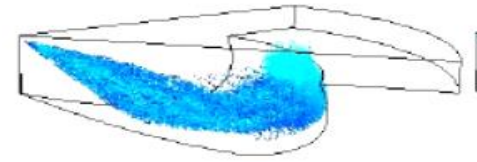

(a)

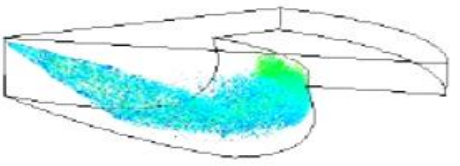

(b)

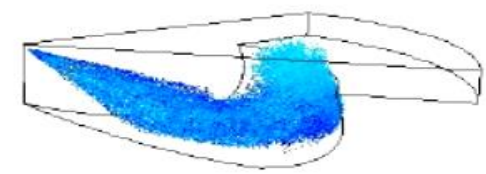

(c)

Figure 7 Diameter Visualization of the Three Types of Biodiesel-Enviromental Things

(a) Castor Biodiesel (b) Coconut Biodiesel (c) Solid MGB Biodiesel = 1 ms with Pi = 350 Bar gauge and Pc $=35$ Bar gauge

Meanwhile, the smallest diameter is dark blue, where the diameter of the castor biodiesel is $0.00244 \mathrm{~mm}$, coconut biodiesel is $0.00163 \mathrm{~mm}$, and used cooking oil biodiesel is $0.00322 \mathrm{~mm}$. This is largely determined by the properties of the biodiesel itself. Biodiesel with lower density, viscosity, and surface tension will have a smaller SMD size, due to faster droplet secondary break up because it is less resistant to friction with air in the chamber. So that the number of particles that form the dispersion pattern is more spread out.

\subsubsection{Comparison of Experiment Results with CFD Program}

Coconut at $\mathrm{Pi}=200$ bar $\mathrm{Pc}=6$ bar with $\mathrm{t}=2.5 \mathrm{~ms}$

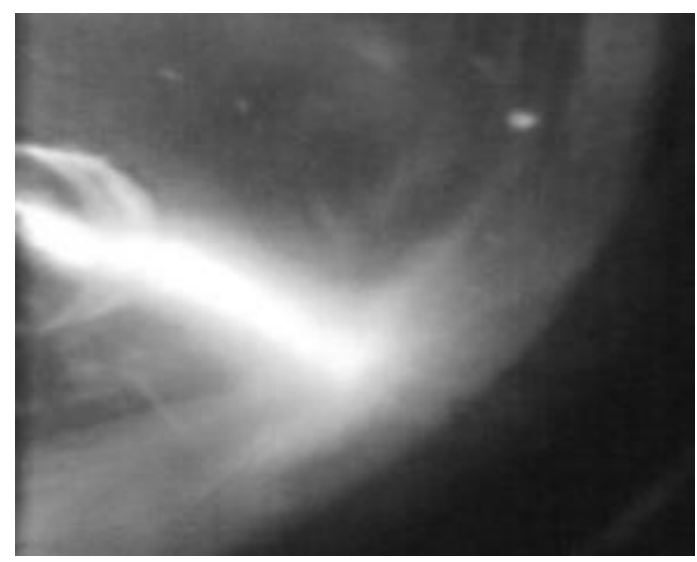

Figure 8 Coconut at $\mathrm{Pi}=350$ bar $\mathrm{Pc}=35$ bar with $\mathrm{t}=0.5 \mathrm{~ms}$ 


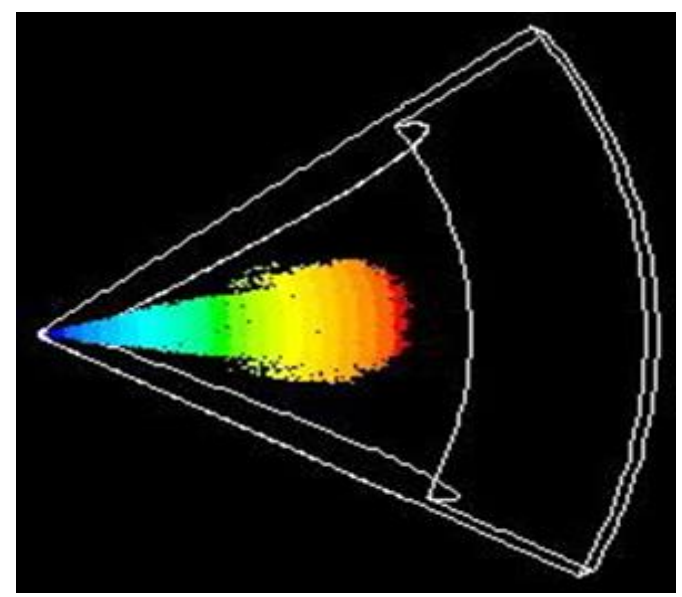

Figure 9 Enviromental Spray Pattern between Experiment and Visualization at Different Pressure and Time

In the picture above, it can be seen that the experimental and visualization results have similarities in the spray pattern, although the operating conditions are different. This proves that the results of visualization with CFD are considered valid.

\section{Conclusion}

The conclusions that can be obtained from the results of numerical simulations and mathematical calculations for the three types of Biodiesels Enviromental Things (castor, coconut, MGB) are as follows:

- Mass flow rate at an injection pressure of 350 bar gauge and a chamber pressure of 35 bar gauge, castor biodiesel is $19.1 \mathrm{~g} / \mathrm{s}$, coconut biodiesel is $18.8 \mathrm{~g} / \mathrm{s}$ and MGB is $19.2 \mathrm{~g} / \mathrm{s}$.

- At the time after the start of injection, the penetration length at $\mathrm{t}=0.5 \mathrm{~ms}$ is $70.5 \mathrm{~mm}$ castor biodiesel, 68.3 mm coconut biodiesel, and 74.6 mm MGB biodiesel.

- At an injection pressure of 350 bar and a chamber pressure of 35 bar from the simulation results of CFD, the spray angle of Castor Biodiesel is $28^{\circ}$, Coconut Biodiesel is $30^{\circ}$ and MGB Biodiesel is $26^{\circ}$.

- The average droplet size (SMD) for chamber pressure increases from 1 bar to 35 bar, the decrease in SMD size is $17.7 \mathrm{~m}$ for MGB biodiesel, $14.5 \mathrm{~m}$ for Castor biodiesel, and $11.3 \mathrm{~m}$ for coconut biodiesel.

- The decrease in the physical properties of the fuel (density, viscosity, surface tension) affects the spray angle, spray length, grain diameter, and SMD.

\subsection{Future work}

The following are some future works to improve further research.

- It is necessary to conduct a numerical simulation study of CFD with different injection pressures on the three Biodiesels Enviromental Things (castor, coconut, MGB).

- It is necessary to conduct further research and more in-depth analysis on the process of combustion of the three types of Biodiesels Enviromental Things (castor, coconut, MGB) and their effect on the diesel engine after the combustion process occurs.

\section{Compliance with ethical standards}

\section{Acknowledgments}

The authors greatly acknowledge the support from Naval Technology College, STTAL Surabaya Indonesia for providing the necessary resources to carry out this research work. The authors are also grateful to the anonymous reviewers and journal editorial board for their many insightful comments, which have significantly improved this article. 


\section{Disclosure of conflict of interest}

The authors declared no potential conflicts of interest with respect to the research, authorship, and/or publication of this article.

\section{References}

[1] Arismunandar, Wiranto and Tsuda, Koichi, High Speed Diesel Motor, Pradnya Paramita, Jakarta. 1986.

[2] Arismunandar, Wiranto, Motor Fuel Torak, ITB, Bandung. 1988.

[3] Alimuddin, Characteristics of Biodiesel Spray Hitting the Combustion Chamber with Piston Type M-System in a Pressure Combustion Chamber, ITS, Surabaya. 2009.

[4] Bastari A, Suharyo OS. Analysis of the Implementation of Occupational Safety Program Efforts to Improve Work Productivity with Fault Tree Analysis Approach. International Journal of Progressive Sciences and Technologies. 2020; 23(2): 728-733.

[5] Bastari A, Bandono A, Suharyo OS. The development strategy of smart campus for improving excellent navy human resources. Global Journal of Engineering and Technology Advances. 2021; 6(2): 033-043.

[6] Faeth, Gm, Spray Combustion Phenomena, Michigan University, USA. 1996.

[7] Heywood, John B. Internal Combustion Engine Fundamentals, McGraw-Hill Book Company, Singapore. 1976.

[8] Kusna, Dwi. Characteristics of Mexican Hat Piston Wall Impact Spray with Biodiesel Fuel in a Pressure Combustion Chamber, ITS, Surabaya. 2009.

[9] Lee Yong Sang, Ryu Uk Sung. Current Issues On Spray-Wall Interaction Phenomena, Seoul, Korea. 2005.

[10] Prima, Erwin, Tjokrowisastro, Eddy H, et.al. Numerical Modeling of Secondary Breakup and CPO evaporation time with Temperature Variations and Initial Heating, Bachelor's Final Project, Department of Mechanical Engineering, FTI-ITS. 2003.

[11] Rahman, Abdul, Characteristics of D-System Piston Wall Impact Spray with Biodiesel Fuel in a Combustion Chamber, ITS, Surabaya. 2009.

[12] Reitz, Rolf D. Spray Technology Short Course, Computer Modeling of Spray, Mechanical Engineering Department, University of Wisconsin. 1996.

[13] Sutrisno S, Suharyo O. S. Air System Analysis in Engineering Room of the Vessel Ship. International Journal of Progressive Sciences and Technologies. 2020; 23(2): 606-611.

[14] Sutrisno S, Kusdiana W, Nugroho A, Rahman A. Analysis of fuel quality effect on the lifetime from a high-pressure pump of engine MTU 12 V 4000 M 71. Journal Asro-Sttal-International Journal. 2020; 11(2): 193-200.

[15] Sutrisno S, Bastari A, Suharyo OS. The Comparison Study of Cathodic Protection System Of Victim Anoda Between Zink Anoda (Zn) And Aluminum Anoda (Al). International Journal of Progressive Sciences and Technologies. 2021; 24(1): 183-193.

[16] Tuakia, Firman, Fundamentals of CFD Using Fluent, Informatics, Bandung. 2008.

[17] Tjokrowisastro EH, Suwarmin, Nur Ikhwan. Feasibility Test of Vegetable Oil as Diesel Motor Fuel in Transportation Vehicles Based on Spray Characteristics, Research Project Grant, Department of Mechanical Engineering, FTI-ITS. 2003.

[18] Vegburner. Direct Injection Combustion Chamber Design, http://vegburner.co.uk/. www.esdm.go.id. Energy Data in the Household Sector. Transportation Sector. Industrial Sector. Petroleum Energy. Coal Energy.

[19] Wåhlin, Fredrik, Experimental Investigation of Impinging Diesel Sprays for HCCI Combustion, Stockholm. 2007. 